\title{
PERANAN MADRASAH DALAM MENINGKATKAN KEMAMPUAN BAHASA ARAB SEBAGAI BAHASA INTERNASIONAL
}

\author{
Risvia Vahrotun Nisa' \\ MA Mamba'ul Ulum Metro \\ Email: risvia27@gmail.com
}

\begin{abstract}
Madrasah is one form of Islamic educational institution that has a long history, originated from an informal education in the form of da'wah Islamiyah, then increased in the form of halaqah, until finally developed in the institution of formal education in the form of madrasah. Among one of the Islamic educational institutions that teach Arabic is Madrasah starting from Ibtida'iyah. Tsanawiyah, and Aliyah levels. In these three levels of education Arabic is presented in a classical manner with different materials tailored to their respective levels. Politically-internationally, Arabic has now been recognized as an international language and is also used as one of the official diplomatic languages in the United Nations (UN) forum. Some nonArab countries in the world, such as Malaysia, have even acknowledged Arabic in their country and give an appreciation of the existence of Arabic writing in public places. As a branch of science that stands alone, Arabic has a unique systematic and structure. Arabic learning is generally the same as other foreign language learning, which aims to achieve four kinds of skills, namely listening, speaking, reading, and writing. The skill is achieved by a learning process involving important elements such as curriculum, teaching materials, teachers, teaching methods and learning, as well as learning facilities.
\end{abstract}

Keywords: Scool, Arabic, International Learning

\begin{abstract}
Abstrak
Madrasah adalah salah satu bentuk lembaga pendidikan Islam yang memiliki sejarah panjang, berawal dari pendidikan yang bersifat informal dalam bentuk dakwah Islamiyah, kemudian mengalami peningkatan dalam bentuk halaqah, hingga akhirnya berkembang dalam lembaga pendidikan formal dalam bentuk madrasah. Diantara salah satu lembaga pendidikan Islam yang mengajarkan Bahasa Arab adalah Madrasah mulai dari tingkat Ibtida'iyah, Tsanawiyah, dan Aliyah. Pada ketiga jenjang pendidikan ini Bahasa Arab
\end{abstract}


dijarkan secara klasikal dengan materi-materi yang berbeda disesuaikan dengan tingkatan masing-masing. Secara politis-internasional, bahasa Arab kini sudah diakui sebagai bahasa internasional dan digunakan juga sebagai salah satu bahasa diplomasi resmi di forum Perserikatan Bangsa-bangsa (PBB). Beberapa negara non-Arab di dunia, seperti Malaysia, bahkan sudah mengakui bahasa Arab di negaranya dan memberikan apresiasi berupa adanya tulisan-tulisan berbahasa Arab di tempat-tempat umum. Sebagai cabang ilmu yang berdiri sendiri, bahasa Arab memiliki sistematika dan struktur yang khas. Pembelajaran bahasa Arab secara umum sama seperti pembelajaran bahasa asing lainnya, yaitu bertujuan mencapai empat ragam kemahiran, yaitu menyimak, berbicara, membaca, dan menulis. Kemahiran itu dicapai dengan proses pembelajaran yang melibatkan unsur-unsur penting seperti kurikulum, bahan ajar, guru, metode pengajaran dan pembelajaran, serta fasilitas pembelajaran.

Kata Kunci: Madrasah, Pembelajaran Bahasa Arab, Internasional.

\section{A. Pendahuluan}

Madrasah adalah salah satu bentuk lembaga pendidikan Islam yang memiliki sejarah panjang, berawal dari pendidikan yang bersifat informal dalam bentuk dakwah Islamiyah, kemudian mengalami peningkatan dalam bentuk halaqah, hingga akhirnya berkembang dalam lembaga pendidikan formal dalam bentuk madrasah ${ }^{1}$.

Diantara salah satu lembaga pendidikan Islam yang mengajarkan Bahasa Arab adalah Madrasah mulai dari tingkat Ibtida'iyah, Tsanawiyah, dan Aliyah. Pada ketiga jenjang pendidikan ini Bahasa Arab dijarkan secara klasikal dengan materi-materi yang berbeda disesuaikan dengan tingkatan masing-masing.

Pembelajaran bahasa Arab yang telah dilaksanakan dilembaga pendidikan yang berupa Madrasah ini telah mengalami pergantian kurikulum secara berulang, dengan asumsi bisa menemukan solusi yang tepat untuk menyelesaikan permasalah pembelajaran bahasa Arab.

${ }^{1}$ Moh. Toriqul Chaer, Peran Madrasah Dalam Menhadapi Era Globalisasi dan Budaya. Muaddib Vol No. 2 Juli-Desember 2016 hal. 200. 
Namun, sesuai dengan penjelasan yang dikemukakan oleh Zakki Fuad bahwa realita pembelajaran bahasa Arab yang telah dilaksanakan di lembaga pendidikan tersebut hasil yang didapatkan belum sampai pada tingkat "mampu menguasai dan menerapkan dengan baik", bahkan prosentase keberhasilannya tergolong rendah ${ }^{2}$.

Sebagai upaya untuk mengoptimalkan tujuan pembelajaran bahasa Arab di lembaga pendidikan Islam maka, lembaga pendidikan Islam baik itu negeri ataupun swasta salah satunya adalah Madrasah, haruslah bisa mendesain dan mengembangkan pembelajaran bahasa Arab yang berorientasi pada penguasaaan empat keterampilan bahasa, yang memfungsikan bahasa menjadi alat komunikasi seseorang dengan orang lain dan menjadi penghubung antar masyarakat suatu bangsa dengan bangsa yang lain. Dalam hal ini bahasa merupakan salah satu faktor penting yang dapat mempererat hubungan dan menciptakan saling pengertian antar bangsa. ${ }^{3}$

Kemampuan bahasa Arab yang diajarkan ada di Madrasah saat ini belum bisa memposisikan bahasa Arab menjadi bahasa Internasional. Padahal hakikatnya pembelajaran bahasa Arab adalah belajar berkomunikasi. Oleh sebab itu, tujuan utama pembelajaran bahasa Arab yang ada di lembaga pendidikan Madrasahharus diarahkan untuk meningkatkan kemampuan siswa dalam berkomunikasi dengan bahasa Arab, baik secara lisan maupun tertulis ${ }^{4}$. Pengertian komunikasi yang dimaksud adalah memahami dan menggungkapkan informasi, pikiran,

${ }^{2}$ Ah. Zakki Fuad, Problematika Pembelajaran bahasa Arab Di Indonesia, EDUKATA, Vol 2, No. 1, Februari 2015. hal. 11-20.

${ }^{3}$ Muhammad Hidayaturrahman, Peran Lembaga pengembangan bahasa Asing dalam meningkatkan kemampuan berbicara bahasa Arab, Tesis, Yogyakarta, 2015, Hal. 2

${ }^{4}$ Mahmud Rusydi Khathir, dkk, thuruq tadris al-lughah al-arabiyah wa al-tarbiyah al-diniyah fi dhau'i al-ittijahaal-tarbawiyah al-haditsah (Kairo: dar al-ma'arif, 1983), hlm. 19-20 
perasaan serta mengembangkan ilmu pengetahuan, teknologi, dan budaya denganmenggunakan bahasa Arab.

Bahasa Arab merupakan alat untuk berkomunikasi secara lisan dan tulis.Berkomunikasi adalah memahami dan mengungkapkan informasi, pikiran,perasaan, dan mengembangkan ilmu pengetahuan, teknologi, dan budaya. Kemampuan berkomunikasi dalam pengertian yang utuh adalahkemampuan berwacana, yakni kemampuan memahami dan/atau menghasilkanteks lisan dan/atau tulis yang direalisasikan dalam empat keterampilanberbahasa, yaitu mendengarkan (istima'), berbicara (kalam), membaca (qira'ah)dan menulis (kitabah) $)^{5}$. Keempat keterampilan inilah yang digunakan untukmenanggapi atau menciptakan wacana dalam kehidupan bermasyarakat.

Pentingnya bahasa Arab ini kemudian membuka jalan bagi lembaga pendidikan untuk memberikan pengajaran bahasa Arab bagi peserta didik. Dalam mengkaji bidang ilmu apa pun, para pelajar diharuskan menguasai bahasa Arab sebagai elemen dasar bagi penguasaan ilmu pengetahuan di tahap berikutnya. Dalam kajian Islam, utamanya, pembelajaran dan penguasaan bahasa Arab mutlak diperlukan. Itulah dasar bagi lembaga pendidikan Islam untuk menempatkan bahasa Arab dalam posisi yang penting.

Sebagai cabang ilmu yang berdiri sendiri, bahasa Arab memiliki sistematika dan struktur yang khas. Pembelajaran bahasa Arab secara umum sama seperti pembelajaran bahasa asing lainnya, yaitu bertujuan mencapai empat ragam kemahiran, yaitu menyimak, berbicara, membaca, dan menulis. Kemahiran itu dicapai dengan proses pembelajaran yang melibatkan unsur-unsur penting seperti kurikulum,

${ }^{5}$ Rusydi Ahmad Tha'imah, dkk ta'lim al-lughah ittishlm.iyan baina al-manahij wa al-istiratiijiyaat, (mathba'ah bani iznanis : Maroko, 2006), hlm. 39. 
bahan ajar, guru, metode pengajaran dan pembelajaran, serta fasilitas pembelajaran $^{6}$.

Keseluruhan unsur tersebut berperan penting dalam proses pembelajaran. Para pihak terkait, seperti guru dan sekolah, bertanggung jawab atas pemenuhan dan ketersediaan unsur-unsur yang dapat menyukseskan proses pembelajaran bahasa Arab di Madrasah. Dari sinilah Lembaga Madrasah mempunyai peran besar di dalam meningkatkan kemampuan bahasa Arab sebagai bahasa Internasional.

Melihat latar belakang di atas, maka penulis akan memaparkan dalam makalahnya peranan Madrasah dalam meningkatkan kemampuan bahasa Arab sebagai bahasa Internasional.

\section{B. Pembahasan}

\section{Bahasa Arab Sebagai Bahasa Internasional.}

Pada masa kini bahasa Arab merupakan salah satu bahasa yang "penting" dari bahasa-bahasa dunia yang digunakan sekitar 200 juta penutur di 19 negara-negara Arab. Seperti halnya bahasabahasa dunia lain, bahasa Arab adalah bahasa komunikasi ilmiah dan nonilmiah) dan bahasa kebudayaan. Ketika Barat mengalami the dark ages bahasa Arab tampil sebagai bahasa ilmiah dan bahasa komunikasi internasional pada masa the golden ages of Islam pada rentang waktu tahun 650 sampai tahun 1250.

Sejarah mencatat, ketika Baghdad dan Andalusia menjadi pusat peradaban dan ilmu pengetahuan, bangsa Eropa yang menjadi penduduk asli Andalusia menggunakan bahasa Arab dan adatistiadat Arab dalam kehidupan sehari-hari. Raja-raja Spanyol 
nonmuslim seperti Peter I, raja Aragon, hanya mengenal huruf Arab. Alfonso IV mencetak mata uang dengan memakai huruf Arab. Di Sicilia, Raja Normandia, Roger I, menjadikan istananya sebagai tempat pertemuan para filsuf, dokter-dokter, dan ahli Islam lainnya dalam berbagai bidang ilmu pengetahuan yang ditimba dari kebudayaan yang berbahasa Arab. Roger II dalam pelbagai hal banyak dipengaruhi kebudayaan Islam. Pakaian kebesaran dikenakannya adalah pakaian Arab; gerejanya dihiasi dengan ukiran dan tulisan-tulisan Arab.

Peradaban Islam dan Arab pada masa itu bukan hanya berpengaruh bagi bangsa Eropa yang berada di bawah atau di bekas kekuasaan Islam, tetapi juga bagi bangsa Eropa yang lain seperti Perancis, Inggris, Jerman dan Italia. Pemuka-pemuka Kristen seperti Gerbert d'Aurillax (yang kemudian menjadi Paus dengan nama Sylvester II (999-1003) belajar di Andalusia; Adebarld belajar di Andalusia dan Sicilia. Adebarld kemudian menjadi salah satu penerjemah handal buku-buku Arab ke dalam bahasa Latin.

Ketika muncul kegairahan untuk mempelajari dunia Arab dan Islam, mereka memandang bahasa Arab sebagai bahasa yang harus dipelajari dalam bidang ilmiah dan filsafat. Pelajaran bahasa Arab kemudian dimasukkan ke dalam kurikulum berbagai perguruan tinggi di Eropa seperti di Bologna (Italia), Chartres (Perancis), Oxford (Inggris) dan Paris. Muncullah penerjemah Arab generasi I yaitu Constantinus Africanus dan Gerard Cremonia. Tujuan mereka adalah memindahkan ilmu pengetahuan dan filsafat dari dunia Islam ke Eropa yang diambil sebagaimana adanya.

Selanjutnya, pelajaran bahasa Arab diajarkan di Roma, Florencia, Padua dan Gregoria (Italia); di Perancis diajarkan di 
Toulouse, Montpellier dan Bordeaux, dan di Inggris diajarkan di Cambridge. Kegiatan mendalami bahasa Arab secara ilmiah ini meredup pasca kekalahanmereka pada perang Salib. Ketika tembok Jerusalem berhasil diruntuhkan pada tanggal 29 September dan pada 2 Oktober 1187 menyerah pada Salahuddin ${ }^{7}$ timbullah "kebencian" dan bias dari kegetiran itu memunculkan gambaran yang salah tentang kebudayaan Islam dan Arab.Memasuki abad ke-20, ditandai dengan munculnya para ilmuwan yang berusaha menulis tentang dunia Islam dan Arab secara ilmiah dan objektif serta mendalam. Dalam tradisi ilmiah yang baru ini, bahasa Arab dan pengenalan teks-teks klasik mendapat kedudukan utama. Mereka mendirikan organisasi, pertemuan-pertemuan ilmiah tentang keAraban, menerbitkan buletin, jurnal-jurnal berbahasa Arab. Apa yang mereka lakukan terhadap studi Islam dan bahasa Arab adalah tulus, dengan derajat nol dari agenda tersembunyi ${ }^{8}$. Jurnal berbahasa Arab yang masih diterima secara cuma-cuma oleh Program Studi Arab Fakultas Ilmu Pengetahuan Budaya Universitas Indonesia adalah jurnal Fikr wa Fann dan Deutschland yang diterbitkan oleh pemerintah Jerman ${ }^{9}$.

Bahasa Arab bukan hanya sekedar bahasa Agama Islam atau bahasa Al Quran, Bahasa Arab adalah bahasa Internasional memiliki peran yang sangat besar dalam perkembangan ilmu pengetahuan dan teknologi melalui pengkajian dua sumber ilmu pengetahuan yaitu Al Quran dan Hadits Nabi, secara politis-

7 Nicolle, David. Hattin 1187:Saladin's Greatest Victory atau Hattin 1187 Kemenangan Terakbar Shalahuddin. Terjemahan. (Jakarta: Kepustakaan Populer Gramedia, 2008), p. 103.

${ }^{8}$ Abdurrahman Badawi, Mawsūah al-Musytasyriqīn. Terjemahan Ensiklopedi Tokoh Orientalis (Yogyakarta:LKiS, 2003), p. vi.

${ }^{9}$ Jurnal berbahasa Arab ini berisi tentang politik, kebudayaan dan ekonomi. Dapat diakses via www.magazine-deutschland.de 
internasional, bahasa Arab kini sudah diakui sebagai bahasa internasional dan digunakan juga sebagai salah satu bahasa diplomasi resmi di forum Perserikatan Bangsa-bangsa dan dalam hal perkembangan situasi ekonomi global, bahasa Arab mengambil tempat dan peran yang sangat penting. Itu ditunjukkan dengan semakin pentingnya kawasan Timur Tengah, yang notabene mayoritas masyarakatnya berbahasa Arab, sebagai pusat sumber daya energi dan mineral dunia. Berbagai kalangan di dunia yang berkepentingan dan ingin membuka jalur komunikasi dengan negara-negara Timur Tengah, harus berpikir dan mengambil sikap bahwa mereka sangat membutuhkan penguasaan bahasa Arab, sebagai pintu masuk komunikasi antarbudaya yang kemudian membuka jalan bagi hubungan ekonomi, politik, dan sebagainya.

Penggiatan dan penghidupan bahasa Arab disetiap sektor pendidikan menjadi salah satu faktor penunjang kemajuan peradaban islam sesuai hukum syariah muamalah kehidupan yang berpedoman pada AlQuran dan Hadits menuju umat terbaik (khairu ummah) ${ }^{10}$.

Secara politis-internasional, bahasa Arab kini sudah diakui sebagai bahasa internasional dan digunakan juga sebagai salah satu bahasa diplomasi resmi di forum Perserikatan Bangsa-bangsa (PBB). Beberapa negara non-Arab di dunia, seperti Malaysia, bahkan sudah mengakui bahasa Arab di negaranya dan memberikan apresiasi berupa adanya tulisan-tulisan berbahasa Arab di tempattempat umum.

Dalam hal perkembangan situasi ekonomi global, bahasa Arab yang sangat penting. Hal itu ditunjukkan dengan semakin

10 http://nenkniya.blogspot.co.id/2013/07/bahasa-arab-sebagai-bahasa.html diakses pada tanggal 25 Oktober 2017 
pentingnya kawasan Timur Tengah, yang notabene mayoritas masyarakatnya berbahasa Arab, sebagai pusat sumber daya energi dan mineral dunia. Berbagai kalangan di dunia yang berkepentingan dan ingin membuka jalur komunikasi dengan negara-negara Timur Tengah, harus berpikir dan mengambil sikap bahwa mereka sangat membutuhkan penguasaan bahasa Arab, sebagai pintu masuk komunikasi antar budaya yang kemudian membuka jalan bagi hubungan ekonomi, politik, dan sebagainya; sebagai contoh, Duta Besar Jerman dan Duta Besar Belanda yang bertugas di Indonesia ternyata mampu berbicara dalam bahasa Arab dengan lancar. Sebagai kawasan bisnis baru yang sangat terbuka dan menjanjikan peluang serta prospek yang cerak, Timur Tengah adalah primadona baru yang sedang merebut perhatian banyak kalangan di dunia. Hal itu ditandai pula dengan semakin banyaknya lembaga dan perusahaan dari luar Arab yang berdatangan dan membuka kantor di negara-negara Timur Tengah. Mereka yang berdatangan itu menyadari bahwa bahasa Arab, selain bahasa Inggris, adalah syarat utama komunikasi dan diplomasi sekaligus pendekatan dengan masyarakat dan negara-negara Timur Tengah ${ }^{11}$.

\section{Kemampuan Bahasa Arab di Lembaga Pendidikan Madrasah}

a. Pengertian Madrasah

Kata madrasah dilihat dari segi gramatika bahasa Arab merupakan bentuk kata keterangan tempat (dzaraf makan) dari akar kata darasa. Secara harfiah, kata madrasah adalah sebagai tempat belajar para pelajar, atau tempat untuk memberikan

\footnotetext{
${ }^{11}$ Rahim Razak, Peran Bahasa Arab Sebagai Bahasa Internasional, Makalah Seminar Nasional" Peranan Bahasa Arab Di Era Globalisasi” Universitas Muhammadiyah Makasar, 2017.Hal. 2-3
} 
pelajaran. Sedangkan Malik Fadjar berpendapat bahwa kata madrasah yang berasal dari bahasa Arab itu mempunyai konotasi dengan arti "sekolah", sekalipun bentukan kata "sekolah" bukan murni produk bangsa Indonesia, tetapi dari bahasa asing, yaitu school atau scola. Sebab menurutnya madrasah mengandung arti tempat atau wahana bagi anak dalam mengenyam proses pembelajaran secara terarah, terpimpin dan terkendali. ${ }^{12}$

Secara teknis, maka madrasah menggambarkan proses pembelajaran secara formal yang tidak berbeda dengan sekolah. Hanya saja secara kultural madrasah lebih memiliki konotasi spesifik karena peserta didik mengalami pembelajaran tentang hal-ihwal agama dan keagamaan. Sebagai kelanjutannya, kata madrasah lebih dikenal sebagai sekolah agama.

Sebagai sekolah agama, karena secara sosiologis masyarakat muslim Indonesia tidak menterjemahkan kata "madrasah" ke dalam bahasa Indonesia, sehingga masyarakat lebih memahaminya sebagai lembaga pendidikan Islam, yakni "tempat untuk belajar agama" atau "tempat untuk memberikan pelajaran agama dan keagamaan".

Keberadaan madrasah sebagai lembaga pendidikan Islam di Indonesia, menurut para ahli pendidikan, khususnya dalam bidang sejarah pendidikan Islam, seperti Azyumardi Azra, Maksum, Hasbullah, Steenbrink, Nakosteen, dan lain-lain, sebenarnya bukan merupakan satu mata rantai sejarah tumbuh dan berkembangnya madrasah di masa Islam Klasik. Tetapi madrasah di Indonesia muncul sebagai kelanjutan logis lembaga pendidikan Islam sebelumnya, khususnya Jawa, yaitu pesantren.

${ }^{12}$ Depag. RI, Sejarah Perkembangan Madrasah. Jakarta: Depag RI, 2000, hal. 2 
Pandangan ini, diperkuat oleh suatu kenyataan bahwa masuknya Islam ke Nusantara, baik gelombang pertama (abad ke-7 M) maupun gelombang kedua (abad ke-13 M) tidak diikuti oleh muncul atau berdirinya madrasah. Dengan alasan itu pula, maka secara historis menurut Nurcholish Madjid, pesantren seringkali disebut tidak hanya identik dengan makna keislaman, tetapi juga mengandung makna keaslian Indonesia (indigenous) ${ }^{13}$

b. Kemampuan Bahasa Arab di Madrasah

Bahasa Arab sebagai salah satu mata pelajaran sudah tidak asing lagi bagi umat Islam terutama di Indonesia. Bahasa Arab sebagai mata pelajaran telah diajarkan pada lembaga pendidikan dari tingkat dasar/ibtidaiyah (kelas IV) sampai Perguruan Tinggi baik PTAI maupun PTU.

Jika dikatakan bahwa bahasa Arab adalah bahasa agama Islam, maka konsekuensinya adalah untuk memahami ilmu-ilmu agama Islam dipersyaratkan menguasai bahasa Arab. Sebab sumber ilmu-ilmu agama Islam ditulis dengan bahasa Arab. Sehingga agama Islam dan bahasa Arab bagaikan dua sisi mata uang yang tidak bisa dipisahkan. Sementara itu, jika dikatakan bahwa bahasa Arab adalah bahasa asing, maka konsekuensinya adalah bahasa Arab diposisikan sebagai bahasa komunikasi yang bukan sebagai prasyarat untuk memahami ilmu-ilmu agama Islam.

Mata pelajaran Bahasa Arab di Madrasah masuk pada struktur kelompok mata pelajaran Pendidikan Agama Islam. Adapun karakteritik Bahasa Arab adalah : Bahasa Arab

${ }^{13}$ H. Maksum, Madrasah, Sejarah dan Perkembangannya. Jakarta: Logos Wacana Ilmu, 1999, hal. 80-81 
merupakan mata pelajaran bahasa yang diarahkan untuk mendorong, membimbing, mengembangkan, dan membina kemampuan serta menumbuhkan sikap positif terhasap Bahasa Arab, baik reseptif maupun produktif. Kemampuan reseptif yaitu kemampuan untuk memahami pembicaraan orang lain dan memahami bacaan. Kemampuan produktif yaitu kemampuan menggunakan bahasa sebagai alat komunikasi baik secara lisan maupun secara tertulis. Kemampuan berbahasa Arab serta sikap positif terhadap bahasa Arab tersebut sangat penting dalam membantu memahami sumber ajaran Isalam yaitu al-Qur'an dan al- Hadis, serta kitab-kitab berbahasa Arab yang berkenaan dengan Islam bagi peserta didik. Untuk itu, Bahasa Arab di Madrasah dipersiapkan untuk pencapaian kompetensi dasar berbahasa, yang mencakup empat keterampilan berbahasa yang diajarkan secara integral, yaitu menyimak (mahaaratu al istimaa'), berbicara (mahaaratu al-kalaam), membaca (mahaaratul al Qiraa'ah), dan menulis (mahaaratu al kitaabah).

Adapun tujuan dan ruang lingkup mata pelajaran bahasa Arab di tingkat MI, Mts, dan MA adalah sebagai berikut: ${ }^{14}$

a. Tujuan dan Ruang Lingkup Bahasa Arab di Madrasah Ibtidaiyah

1) Tujuan Bahasa Arab Madrasah Ibtidaiyah

Mata pelajaran Bahasa Arab merupakan suatu mata pelajaran yang diarahkan untuk mendorong, membimbing, mengembangkan, dan membina kemampuan serta menumbuhkan sikap positif terhadap bahasa Arab baik

14 PMA RI NO 000912 tahun 2013 tentang Kurikulum Madrasah 2013 Mata Pelajaran Pendidikan Agama Islam dan bahasa Arab. 
reseptif maupun produktif. Kemampuan reseptif yaitu kemampuan untuk memahami pembicaraan orang lain dan memahami bacaan. Kemampuan produktif yaitu kemampuan menggunakan bahasa sebagai alat komunikasi baik secara lisan maupun tulis. Kemampuan berbahasa Arab serta sikap positif terhadap bahasa Arab tersebut sangat penting dalam membantu memahami sumber ajaran Islam yaitu al-Qur'an dan hadis, serta kitab-kitab berbahasa Arab yang berkenaan dengan Islam bagi peserta didik.

Untuk itu, bahasa Arab di madrasah dipersiapkan untuk pencapaian kompetensi dasar berbahasa, yang mencakup empat keterampilan berbahasa yang diajarkan secara integral, yaitu menyimak, berbicara, membaca, dan menulis. Meskipun begitu, pada tingkat pendidikan dasar (elementary) dititikberatkan pada kecakapan menyimak dan berbicara sebagai landasan berbahasa. Pada tingkat pendidikan menengah (intermediate), keempat kecakapan berbahasa diajarkan secara seimbang. Adapun pada tingkat pendidikan lanjut (advanced) dikonsentrasikan pada kecakapan membaca dan menulis, sehingga peserta didik diharapkan mampu mengakses berbagai referensi berbahasa Arab. Mata pelajaran Bahasa Arab memiliki tujuan sebagai berikut:

2) Mengembangkan kemampuan berkomunikasi dalam bahasa Arab, baik lisan maupun tulis, yang mencakup empat kecakapan berbahasa, yakni menyimak (istima'), berbicara (kalam), membaca (qira'ah), dan menulis (kitabah). 
3) Menumbuhkan kesadaran tentang pentingnya bahasa Arab sebagai salah satu bahasa asing untuk menjadi alat utama belajar, khususnya dalam mengkaji sumber-sumber ajaran Islam.

4) Mengembangkan pemahaman tentang saling keterkaitan antara bahasa dan budaya serta memperluas cakrawala budaya. Dengan demikian, peserta didik diharapkan memiliki wawasan lintas budaya dan melibatkan diri dalam keragaman budaya.

b. Ruang Lingkup Bahasa Arab di Madrasah Ibtidaiyah

Ruang lingkup pelajaran Bahasa Arab di Madrasah Ibtidaiyah meliputi tema-tema tentang perkenalan, peralatan madrasah, pekerjaan, alamat, keluarga, anggota badan, di rumah, di kebun, di madrasah, di laboratorium, di perpustakaan, di kantin, jam, kegiatan sehari-hari, pekerjaan, rumah, dan rekreasi.

1) Tujuan dan Ruang Lingkup Bahasa Arab di Madrasah Tsanawiyah

a) Tujuan Kelompok Mata Pelajaran Bahasa Arab di Madrasah Tsanawiyah

Mata pelajaran Bahasa Arab merupakan suatu mata pelajaran yang diarahkan untuk mendorong, membimbing, mengembangkan, dan membina kemampuan serta menumbuhkan sikap positif terhadap bahasa Arab baik reseptif maupun produktif. Kemampuan reseptif yaitu kemampuan untuk memahami pembicaraan orang lain dan memahami bacaan. Kemampuan produktif yaitu kemampuan 
menggunakan bahasa sebagai alat komunikasi baik secara lisan maupun secara tertulis.

Kemampuan berbahasa Arab serta sikap positif terhadap bahasa Arab tersebut sangat penting dalam membantu memahami sumber ajaran Islam yaitu al-Qur'an dan Hadis, serta kitab-kitab berbahasa Arab yang berkenaan dengan Islam bagi peserta didik.

Mata pelajaran Bahasa Arab memiliki tujuan sebagai berikut:

(1) Mengembangkan kemampuan berkomunikasi dalam bahasa Arab, baik lisan maupun tulis, yang mencakup empat kecakapan berbahasa, yakni menyimak (istima'), berbicara (kalam), membaca (qira'ah), dan menulis (kitabah).

(2) Menumbuhkan kesadaran tentang pentingnya bahasa Arab sebagai salah satu bahasa asing untuk menjadi alat utama belajar, khususnya dalam mengkaji sumber-sumber ajaran Islam.

(3) Mengembangkan pemahaman tentang saling keterkaitan antara bahasa dan budaya serta memperluas cakrawala budaya. Dengan demikian, peserta didik diharapkan memiliki wawasan lintas budaya dan melibatkan diri dalam keragaman budaya.

b) Ruang Lingkup Bahasa Arab di Madrasah Tsanawiyah Ruang lingkup pelajaran Bahasa Arab di Madrasah Tsanawiyah meliputi tema-tema yang berupa wacana 
lisan dan tulisan berbentuk paparan atau dialog sederhana tentang identitas diri, kehidupan madrasah, kehidupan keluarga, rumah, hobi, profesi, kegiatan keagamaan, dan lingkungan.

c) Tujuan dan Ruang Lingkup Bahasa Arab di Madrasah Aliyah

Tujuan Bahasa Arab di Madrasah Aliyah

Mata pelajaran bahasa Arab merupakan suatu mata pelajaran yang diarahkan untuk mendorong, membimbing, mengembangkan, dan membina kemampuan serta menumbuhkan sikap positif terhasap bahasa Arab, baik reseptif maupun produktif. Kemampuan reseptif yaitu kemampuan untuk memahami pembicaraan orang lain dan memahami bacaan. Kemampuan produktif yaitu kemampuan menggunakan bahasa sebagai alat komunikasi baik secara lisan maupun secara tertulis.

Kemampuan berbahasa Arab serta sikap positif terhadap bahasa Arab tersebut sangat penting dalam membantu memahami sumber ajaran Isalam yaitu alQur'an dan al- hadis, serta kitab-kitab berbahasa Arab yang berkenaan dengan Islam bagi peserta didik.

Untuk itu, bahasa Arab di Madrasah Aliyah dipersiapkan untuk pencapaian kompetensi dasar berbahasa, yang mencakup empat keterampilan berbahasa yang diajarkan secara integral, yaitu menyimak, berbicara, membaca, dan menulis. Meskipun 
begitu, pada tingkat pendidikan dasar (elementary) dititikberatkan pada kecakapan menyimak dan berbicara sebagai landasan berbahasa.

Pada tingkat pendidikan menengah (intermediate), keempat kecakapan berbahasa diajarkan secara seimbang. Pada tingkat pendidikan lanjut (advanced), dikonsentrasikan pada kecakapan membaca dan menulis, sehingga peserta didik diharapkan mampu mengakses berbagai referensi berbahasa Arab.

Mata pelajaran bahasa Arab di Madrasah Aliyah memiliki tujuan sebagai berikut:1) Mengembangkan kemampuan berkomunikasi dalam bahasa Arab, baik lisan maupun tulis yang mencakup empat kecakapan berbahasa, yakni menyimak (istima'), berbicara (kalam), membaca (qira'ah), dan menulis (kitabah).2) Menumbuhkan kesadaran tentang pentingnya bahasa Arab sebagai salah satu bahasa asing untuk menjadi alat utama belajar, khususnya dalam mengkaji sumber-sumber ajaran Islam.3) Mengembangkan pemahaman tentang saling keterkaitan antara bahasa dan budaya serta memperluas cakrawala budaya. Dengan demikian, peserta didik diharapkan memiliki wawasan lintas budaya dan melibatkan diri dalam keragaman budaya.

d) Ruang Lingkup Kelompok Bahasa Arab di Madrasah Aliyah 
Mata pelajaran bahasa Arab di Madrasah Aliyah terdiri atas bahan yang berupa wacana lisan dan tulisan berbentuk paparan atau dialog tentang perkenalan, kehidupan keluarga, hobi, pekerjaan, remaja, kesehatan, fasilitas umum, pariwisata, kisahkisah Islam, wawasan Islam, hari-hari besar Islamdan tokoh-tokoh Islam untuk melatih keempat aspek kemampuan berbahasa, yaitu menyimak, berbicara, membaca, dan menulis.

Dari penjelasan di atas dapatlah dikatakan bahwasanya materi-materi pelejaran bahasa Arab yang diajarkan di Madrasah mengacu pada kurikulum yang telah ditetapkan oleh pemerintah.

Adapun komponen yang dapat mendukung tercapainya kemampuan berbahasa Arab yang telah digariskan pada kurikulum tersebut ada 6 hal seperti yang telah dijelaskan oleh Arifin, 6 komponen tersebut adalah: yaitu: 1) guru, 2) siswa, 3) materi/kurikulum, 4) sarana dan prasarana, 5) manajemen atau pengelolaan, dan 6) lingkungan ${ }^{15}$.

Keenam komponen inilah yang akan menentukan terbentuknya kemampuan siswa di Madrasah dimana ia belajar. Madrasah sebagai lembaga pendidikan yang mengajarkan bahasa Arab hendaknya memperhatikan keenam komponen ini

${ }^{15}$ Zainal Arifin, Penerapan Kompetensi Pedagogik Dan Kompetensi Profesional di Kalangan Guru Bahasa Arab pada Madrasah Tsanawiyah Se-Kabupaten Rembang (Studi Deskriptif Evaluatif), Tesis Pascasarjana Pendidikan Bahasa Arab Malang: Tidak Diterbitkan, h. 1. 
dengan bisa mensinergikannya maka akan terbentuklah kemampuan bahasa Arab yang sesuai dengan kurikulum yang telah ditetapkan.

\section{Peranan Madrasah dalam meningkatkan kemampuan bahasa} Arab sebagai bahasa Internasional.

Bahasa Arab telah menjadi bahasa Internasional yang menempati urutan yang keempat setelah bahasa Perancis, hal menandakan bahwa bahasa Arab dipelajari bukan hanya oleh umat muslim saja tetapi orang-orang non muslim juga ikut serta menjadi bagian pembelajar bahasa ini.

Madrasah sebagai lembaga pendidikan yang mengajarkan bahasa Arab mempunyai peran penting untuk meningkatkan kemampuan bahasa Arab yaitu: peran perencanaan dan pelaksana kurikulum bahasa Arab, peran sinergis (antara steakholder sekolah dalam melaksanakan kegiatan pembelajaran terutama bahasa Arab dengan siswa, serta mendorong siswa agar mempunyai semangat belajar dan meningkatkan kemampuan bahasa Arab mereka masingmasing), peran motivasi (untuk mendorong siswa madrasah mencintai bahasa Arab, peran sosialisasi (untuk mensyiarkan bahasa Arab sebagai alat komunikasi Internasional).

Dewasa ini, pembelajaran bahasa arab khususnya di lembaga pendidikan formal sudah mulai diperhitungkan, termasuk di Indonesia sendiri. Hal ini tidak lepas dari semenjak dipilihnya bahasa arab sebagai salah satu bahasa resmi yang digunakan oleh Perserikatan Bangsa-Bangsa (PBB) yang secara tidak langsung mengangkat derajat bahasa arab sebagai salah satu bahasa internasional selain bahasa 
Spanyol, Inggris, Prancis, dan Mandarin ${ }^{16}$. Maka tidak heran jika kemudian kita melihat sekolah-sekolah formal yang bernaung dibawah kementrian pendidikan menjadikan bahasa arab sebagai salah satu materi yang diajarkan, setara dengan bahasa inggris, prancis, dan lainnya. Tentunya disini, lembaga-lembaga pendidikan dibawah naungan kementrian agama memiliki kesempatan yang lebih besar dalam proses pembelajaran bahasa arab bahkan bahasa arab dijadikan sebagai materi wajib, karena kurang lengkap rasanya jika mempelajari materi keagamaan (islam) tanpa mempelajari bahasa arab yang berkedudukan sebagai bahasa kitab suci dan kitab-kitab ulama klasik islam yang didalamnya memuat ajaran-ajaran agama islam. Oleh karenanya, pembelajaran bahasa arab saat ini merupakan salah satu pelajaran yang penting untuk dipelajari.

Dalam proses pembelajaran (pendidikan), setidaknya ada empat (4) hal yang harus diperhatikan yaitu, tujuan (الهدف), metode (الطريقة), media (الوسائط), dan evaluasi (التقويم). Keempat hal ini saling mempengaruhi satu sama lain. Untuk mencapai keefektifan pembelajaran, tentunya harus ada inovasi dalam setiap unsur tersebut. Inovasi tersebut haruslah sesuai dengan situasi dan kondisi yang sedang berkembang.

Kesuksesan lembaga pendidikan bahasa arab tidak bisa lepas dari sinergi antara konsep dan pelaksanaan manajeman bahasaarab yang baik. Artinya guru bahasa arab harus memahami konsep manajemen pembelajaran bahasaarab dengan baik agar pelaksanaan tujuan-tujuan pendidikan yang telah direncanakan sebelumnya bisa dicapai secara efektif dan efisien sesuai dengan prinsip-prinsip yang

${ }^{16}$ https.www//kompasiana.com//coretan hitam elearning jalan transformasi kebahasa araban. Diakses pada 28 Oktober 2017. 
baku. Dan guru bahasa arab yang baik memiliki sifat ikhlas dan dedikasi yang tinggi pada profesinya.

Guru bahasa arab harus memiliki kompetensi yang mencakup kemampuan memahami prinsip-prinsip pendidikan bahasa arab, mengelola proses belajar mengajar bahasa arab secara konperhensif, menjadi pribadi yang arif dan bijaksana serta teladan yang baik bagi anak didik (teladan dalam bersikap dan teladan dalam berbahasayang baik dan benar), mampu bekerja sama dengan rekan seprofesi dan masyarakat luas demi mewujudkan tujuan-tujuan pendidikan, dan menguasai materi bahasa arab beserta seluruh kompetensinya, memiliki kemampuan mengembangkan bahan ajarnya dan mengajarkan bahasa arab pada anak didik sesuai tugas dan fungsinya, yaitu alat komunikasi.

Pendidikan bahasa arab yang sukses mencerminkan keseimbangan antara konsep dan implementasi kurikulum yang terencana, terorganisir dengan seluruh elemen pendidikan dan masyarakat secara harmonis, dan dievaluasi secara berkesinambungan ${ }^{17}$.

\section{Simpulan}

Bahasa Arab bukan hanya sekedar bahasa Agama Islam atau bahasa Al Quran, Bahasa Arab adalah bahasa Internasional memiliki peran yang sangat besar dalam perkembangan ilmu pengetahuan dan teknologi melalui pengkajian dua sumber ilmu pengetahuan yaitu $\mathrm{Al}$ Quran dan Hadits Nabi, secara politis-internasional, bahasa Arab kini sudah diakui sebagai bahasa internasional dan digunakan juga sebagai salah satu bahasa diplomasi resmi di forum Perserikatan Bangsa-bangsa

17 Muallim Wijaya, Menajemen Pembelajaran Bahasa Arab, Jurnal Lughotuna arabiyah IAI Nurul Jadid, 2016. Hal 2-5 
dan dalam hal perkembangan situasi ekonomi global, bahasa Arab mengambil tempat dan peran yang sangat penting. Bahasa Arab sebagai salah satu mata pelajaran sudah tidak asing lagi bagi umat Islam terutama di Indonesia. Bahasa Arab sebagai mata pelajaran telah diajarkan pada lembaga pendidikan dari tingkat dasar/ibtidaiyah (kelas IV) sampai Perguruan Tinggi baik PTAI maupun PTU. Jika dikatakan bahwa bahasa Arab adalah bahasa agama Islam, maka konsekuensinya adalah untuk memahami ilmu-ilmu agama Islam dipersyaratkan menguasai bahasa Arab. Sebab sumber ilmu-ilmu agama Islam ditulis dengan bahasa Arab. Sehingga agama Islam dan bahasa Arab bagaikan dua sisi mata uang yang tidak bisa dipisahkan. Sementara itu, jika dikatakan bahwa bahasa Arab adalah bahasa asing, maka konsekuensinya adalah bahasa Arab diposisikan sebagai bahasa komunikasi yang bukan sebagai prasyarat untuk memahami ilmu-ilmu agama Islam. Bahasa Arab telah menjadi bahasa Internasional yang menempati urutan yang keempat setelah bahasa Perancis, hal menandakan bahwa bahasa Arab dipelajari bukan hanya oleh umat muslim saja tetapi orang-orang non muslim juga ikut serta menjadi bagian pembelajar bahasa ini. Madrasah sebagai lembaga pendidikan yang mengajarkan bahasa Arab mempunyai peran penting untuk meningkatkan kemampuan bahasa Arab yaitu: peran perencanaan dan pelaksana kurikulum bahasa Arab, peran sinergis (antara steakholder sekolah dalam melaksanakan kegiatan pembelajaran terutama bahasa Arab dengan siswa, serta mendorong siswa agar mempunyai semangat belajar dan meningkatkan kemampuan bahasa Arab mereka masingmasing), peran motivasi (untuk mendorong siswa madrasah mencintai bahasa Arab, peran sosialisasi (untuk mensyiarkan bahasa Arab sebagai alat komunikasi Internasional). 


\section{DAFTAR PUSTAKA}

Abdurrahman Badawi, Mawsūah al-Musytasyriqīn. Terjemahan Ensiklopedi Tokoh Orientalis (Yogyakarta:LKiS, 2003

Ah. Zakki Fuad, Problematika Pembelajaran bahasa Arab Di Indonesia, EDU-KATA, Vol 2, No. 1, Februari 2015

Bahasa Arab pada Madrasah Tsanawiyah Se-Kabupaten Rembang (Studi Deskriptif Evaluatif), Tesis Pascasarjana Pendidikan Bahasa Arab Malang: Tidak Diterbitkan,

Depag. RI, Sejarah Perkembangan Madrasah. Jakarta: Depag RI, 2000

H. Maksum, Madrasah, Sejarah dan Perkembangannya. Jakarta: Logos Wacana Ilmu, 1999

Moh. Toriqul Chaer, Peran Madrasah Dalam Menhadapi Era Globalisasi dan Budaya. Muaddib Vol No. 2 Juli-Desember 2016

Muhammad Hidayaturrahman, Peran Lembaga pengembangan bahasa Asing dalam meningkatkan kemampuan berbicara bahasa Arab , Tesis, Yogyakarta, 2015

Mahmud Rusydi Khathir, dkk, thuruq tadris al-lughah al-arabiyah wa altarbiyah al-diniyah fi dhau'i al-ittijahaat al-tarbawiyah al-haditsah (Kairo: dar al-ma'arif, 1983)

Muallim Wijaya, Menajemen Pembelajaran Bahasa Arab, Jurnal Lughotuna arabiyah IAI Nurul Jadid, 2016

Nur Hizbullah, Zaqiatul Mardiah, Masalah Pengajaran bahasa Arab di Madrasah Aliyah di Jakarta, pada jurnal Al-Azhar indonesia Seri Humaniora Vol 2 No 3 Maret 2014,

Nicolle, David. Hattin 1187:Saladin's Greatest Victory atau Hattin 1187 Kemenangan Terakbar Shalahuddin. Terjemahan. (Jakarta: Kepustakaan Populer Gramedia, 2008

Rusydi Ahmad Tha'imah, dkk ta'lim al-lughah ittishlm.iyan baina almanahij wa al-istiratiijiyaat, (mathba'ah bani iznanis : Maroko, 2006

Rahim Razak, Peran Bahasa Arab Sebagai Bahasa Internasional, Makalah Seminar Nasional" Peranan Bahasa Arab Di Era Globalisasi" Universitas Muhammadiyah Makasar, 2017 
PMA RI NO 000912 tahun 2013 tentang Kurikulum Madrasah 2013 Mata Pelajaran Pendidikan Agama Islam dan bahasa Arab.

Zainal Arifin, Penerapan Kompetensi Pedagogik Dan Kompetensi Profesional di Kalangan Guru

Jurnal berbahasa Arab ini berisi tentang politik, kebudayaan dan ekonomi. Dapat diakses via www.magazine-deutschland.de

https.www//kompasiana.com//coretan hitam elearning jalan transformasi kebahasa araban. Diakses pada 28 Oktober 2017.

http://nenkniya.blogspot.co.id/2013/07/bahasa-arab-sebagai-bahasa.html diakses pada tanggal 25 Oktober 2017 